\title{
Demonstration that progesterone 'blocks' uterine activity in the ewe in vivo by a direct action on the myometrium
}

\author{
S. J. Lye and D. G. Porter \\ Pre-Clinical Veterinary Studies, Department of Anatomy, \\ The Medical School, Bristol BS8 1TD, U.K.
}

\begin{abstract}
Summary. Intrauterine pressure was monitored in vivo in oestrogen-treated ovariectomized ewes before, during and after treatment with progesterone $(50 \mathrm{mg}$ s.c./day for 3 days). Progesterone reversibly reduced the frequency and amplitude of myometrial activity and abolished uterine reactivity to oxytocin (i.v.) and PGF-2 $\alpha$ (intrauterine infusion). The rate of rise of intrauterine pressure during active pressure cycles was significantly reduced. These results confirm that the action of progesterone on the ovine myometrium is comparable to the classic progesterone 'block'. The intrauterine infusion of PGF- $2 \alpha(10 \mu \mathrm{g} / \mathrm{min})$, which elicited a marked mechanical response in the control animals, failed to stimulate the progesterone-'blocked' uterus, suggesting that the inhibition produced by progesterone is due to a direct action of the hormone on the uterine muscle and not to an indirect mechanism operating through endometrial prostaglandin output.
\end{abstract}

\section{Introduction}

There is confusion over the part played by progesterone in maintaining the myometrial quiescence which is characteristic of late pregnancy in the ewe (Hindson, Schofield, Turner \& Wolff, 1965). The well-documented fall in plasma progesterone titres which presages parturition (Bassett, Oxborrow, Smith \& Thorburn, 1969; Fylling, 1969; Stabenfeldt, Drost \& Franti, 1972; Thorburn, Nicol, Bassett, Shutt \& Cox, 1972; Thompson \& Wagner, 1974; Rawlings \& Ward, 1976) suggests that progesterone may 'block' myometrial activity in the ewe and that withdrawal of the 'block' is a prerequisite of parturition as demonstrated in the rabbit by Csapo (1956). However, such a conclusion is not justified at present since not only did Bengtsson \& Schofield (1963) obtain equivocal results when attempting to prolong pregnancy in sheep with progesterone, but Liggins, Grieves, Kendall \& Knox (1972) reported that in ewes treated with $100 \mathrm{mg}$ progesterone daily, parturition commenced even though myometrial progesterone titres were comparable to those of animals up to 28 days before birth. Furthermore, Rawlings \& Ward (1976) found no significant negative correlation between uterine activity and maternal plasma progesterone titres in late pregnant ewes, and it is known that the rate of decline of plasma progesterone varies greatly among individuals (Bassett et al., 1969; Fylling, 1969). These uncertainties have lead to the suggestion (Liggins, 1973; Liggins, Fairclough, Grieves, Forster \& Knox, 1977) that progesterone may not act directly upon the ovine myometrium but may modulate its activity indirectly by controlling endometrial prostaglandin production.

Classically the progesterone 'block' is characterized by (1) a dose-dependent suppression of the amplitude of myometrial contractions, (2) reduction in the rate of rise of pressure during intrauterine pressure cycles and (3) loss of reactivity to oxytocic agents (Csapo, 1956; Schofield, 1957; Csapo \& Takeda, 1965). Because the endocrine environment of the pregnant uterus is complex it is difficult to be sure what action, if any, progesterone has on the myometrium during pregnancy. The nonpregnant ewe provides an endocrinologically simpler system in which to investigate the influence of hormones on uterine activity. There have been several reports which suggest an inhibitory action of progesterone on the ovine myometrium (Naaktgeboren et al., 1973; Croker \& Shelton, 1973; Rousseau \& Prud'homme, 1974; Carrick \& Cupps, 1976; Ruckebusch \& Buene,c1976).However, $10: 00: 11 \mathrm{AM}$ 
because the above authors used intact instead of ovariectomized animals, or did not analyse uterine activity quantitatively, or did not investigate the action of oxytocic substances, these studies have failed to establish fully the precise nature of the inhibition and do not refute the hypothesis that progesterone acts on the myometrium indirectly via the endometrium.

Because of these uncertainties we have reinvestigated the action of progesterone upon the uterine activity in vivo of the ovariectomized ewe, paying particular attention to the criteria of the progesterone 'block' as set out above. To test the hypothesis that progesterone acts indirectly, we examined the effect of oxytocic substances on the progesterone-inhibited uterus. Part of the results of this study have been reported briefly elsewhere (Porter, 1977).

\section{Materials and Methods}

Five Clun ewes and one Hampshire ewe (aged 4-9 years) were used: they were part of a breeding flock which had exhibited normal fecundity up to and including the previous (1975/76) breeding season. The animals, anaesthetized with sodium thiopentone intravenously and maintained with fluothane and oxygen, were ovariectomized through a midline laparotomy. An evacuated, latex balloon ( $6 \mathrm{ml}=$ max. undistended vol.) attached to a polyethylene catheter (i.d. $0.86 \mathrm{~mm}$; 0.d. 1.52 $\mathrm{mm}$ ) and accompanied by an open-ended infusion catheter (i.d. 0.38 mm; o.d. 1.09 mm) was inserted into the lumen of each uterine horn through a small incision in the wall of the uterine body.

Pilot experiments showed that spontaneous contractile activity declined to very low levels unless oestrogen treatment was given and from the day after surgery, therefore, the animals were given daily s.c. injections of $50 \mu \mathrm{g}$ oestradiol-17 $\beta$. Four days after ovariectomy the balloons were filled with 2.5-3.5 ml water. Daily monitoring of intrauterine pressure was then begun by connecting the balloon catheters to Bell \& Howell pressure transducers and a Devices MX4 Pen Recorder for periods of between 1 and $3 \mathrm{~h}$. The animals were treated with progesterone in one of two ways, as indicated below.

\section{Group I: oxytocin and prostaglandin experiments}

Four animals in this group were each subjected to 13-day experimental regimens: Days 1-3, oestradiol (Sigma, London) treatment only $(50 \mu \mathrm{g})$ (Control period), Days 4-6, oestradiol treatment $(50 \mu \mathrm{g})+50 \mathrm{mg}$ progesterone (Sigma, London) in $2.5 \mathrm{ml}$ corn oil (s.c.) (Treatment period), Days $7-13$, oestradiol treatment only $(50 \mu \mathrm{g})$ (Recovery period).

The 4 animals were subjected to three 13-day experimental regimens each, but at least 5 days were allowed to elapse between regimens repeated in the same animal.

The responsiveness of the myometrium to stimulants, before, during and after recovery from progesterone was tested by administration, during separate experimental regimens, of oxytocin (Syntocinon: Sandoz) or prostaglandin (PG) F-2 $\alpha$ (pure substance, I.C.I. Ltd, Cheshire) while intrauterine pressure was being recorded during the Control, and at the end of the Treatment and Recovery periods. The oxytocin ( $500 \mathrm{mu}$ ) was injected intravenously. The PG was dissolved in alcohol and $0.9 \%(\mathrm{w} / \mathrm{v}) \mathrm{NaCl}$ aqueous solution $(6: 100 \mathrm{v} / \mathrm{v})$ and infused directly into the uterine lumen via the infusion catheter, at the rate of $10 \mu \mathrm{g} / \mathrm{min}(600 \mu \mathrm{g}$ PGF- $2 \alpha / \mathrm{ml})$. Infusion of vehicle alone was carried out as a control.

Blood samples $(7 \mathrm{ml})$ were removed from the jugular vein on Days 3,6 and 11-13 in 8 out of the 12 experimental regimens of the 4 ewes. These were promptly heparinized, refrigerated, and centrifuged. The plasma was then removed and stored at $-20^{\circ} \mathrm{C}$ before being analysed for progesterone content by radioimmunoassay. The assays were kindly carried out by Dr R. B. Heap at the A.R.C. Institute of Animal Physiology, Babraham, using method (A) set out in Heap, Gwyn, Laing \& Walters (1973).

Intrauterine pressure records were divided into 10-min sections and analysed for frequency and maximum amplitude of active pressure cycles. We arbitrarily defined an 'active pressure cycle' as any increase in pressure of $10 \mathrm{mmHg}$ or more above the resting pressure which was followed by a fall in pressure of $10 \mathrm{mmHg}$ or more. The results were subjected to a two-way, two-factor analysis of variance (Armitage, 1971). 
Group II: latency period, rate of pressure rise, and recovery

Two of the Group I ewes and 2 additional ewes were used. Each animal, maintained as before on $50 \mu \mathrm{g}$ oestradiol daily, was given a single s.c. injection of $100 \mathrm{mg}$ progesterone in corn oil. Intrauterine pressure was monitored at the time of, and at 16 intervals thereafter up to $200 \mathrm{~h}$ after the injection. At each of the intervals a sample of the IUP was recorded at fast paper speed to permit analysis for rate of pressure rise. Measurements were also made of the maximum amplitude and frequency of pressure cycles so that the timing of both the peak effect of progesterone and the recovery could be determined accurately. The rates of rise of 5 pressure cycles, whenever possible, were measured for each ewe at each time period recorded.

\section{Results}

\section{Oxytocin and prostaglandin experiments}

\section{Control period}

Spontaneous activity. The records of spontaneous intrauterine pressure of the 4 ewes were similar. Pressure cycles occurred regularly, with a frequency of approximately $20 \mathrm{cycles} / 10 \mathrm{~min}$. Maximum amplitude varied among animals from 20 to $50 \mathrm{mmHg}$. Occasionally during a recording period myometrial activity would subside to very low levels for periods of $1 \mathrm{~h}$ or more, but these quiescent periods were infrequent and followed no obviously consistent pattern.

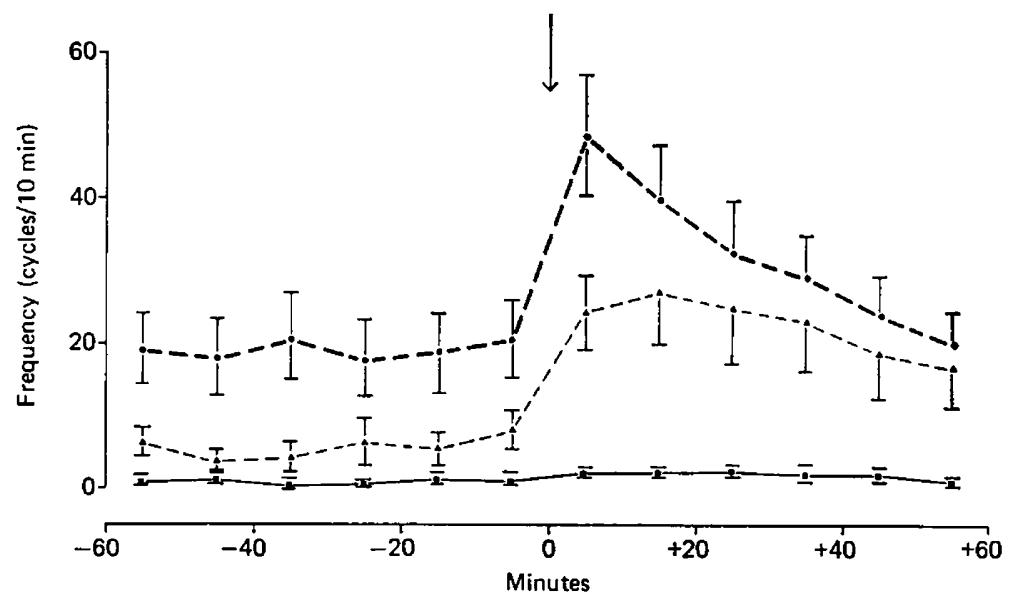

Text-fig. 1. Graph showing changes in frequency $( \pm$ s.e.m.) of intrauterine pressure cycles during 4 experiments in 4 ewes. At 0 min (arrow), $500 \mathrm{mu}$ oxytocin were administered intravenously. $\bullet$, Control; $\square, 72 \mathrm{~h}$ after start of progesterone treatment; $\Delta$, after recovery from progesterone treatment.

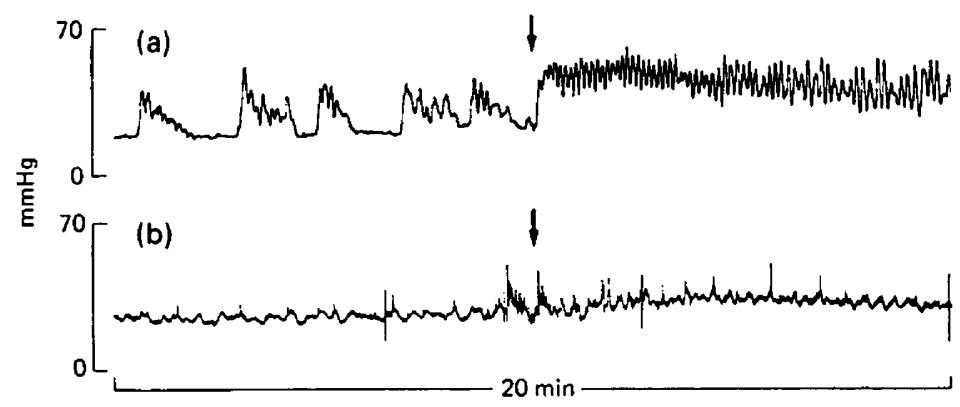

Text-fig. 2. Records of intrauterine pressure from an oestrogen-treated ovariectomized ewe injected i.v. with $\mathbf{5 0 0}$ mu oxytocin (arrow) during the Control (a) and Treatment (b) periodssioscientifica.com at 04/26/2023 10:00:11AM 


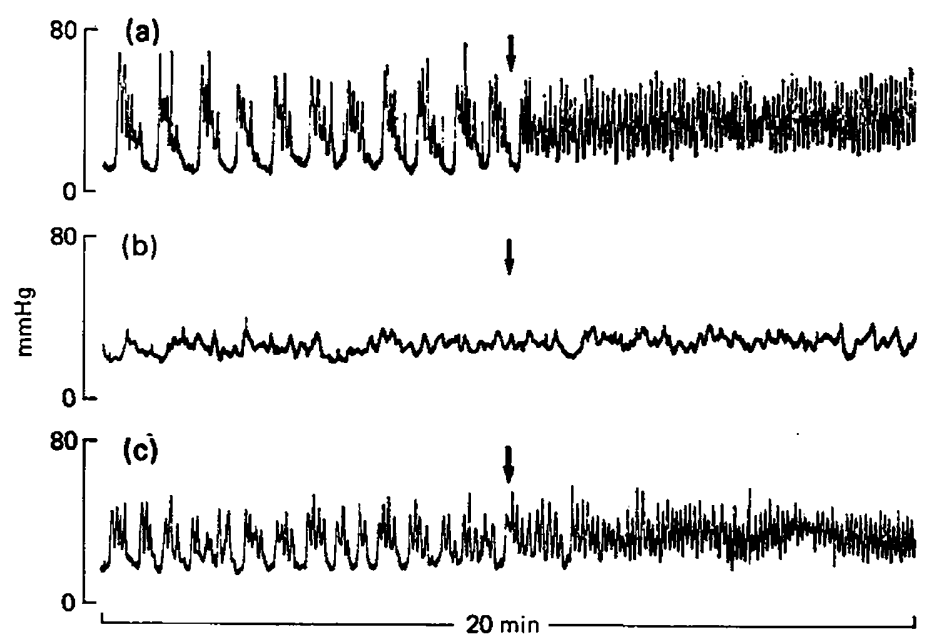

Text-fig. 3. Records of intrauterine pressure from an oestrogen-treated ovariectomized ewe, showing the response to an intraluminal infusion (arrow) of $10 \mu \mathrm{g} \mathrm{PGF-2 \alpha /min} \mathrm{during} \mathrm{the} \mathrm{(a)} \mathrm{Control,} \mathrm{(b)} \mathrm{Treatment}$ and (c) Recovery periods.

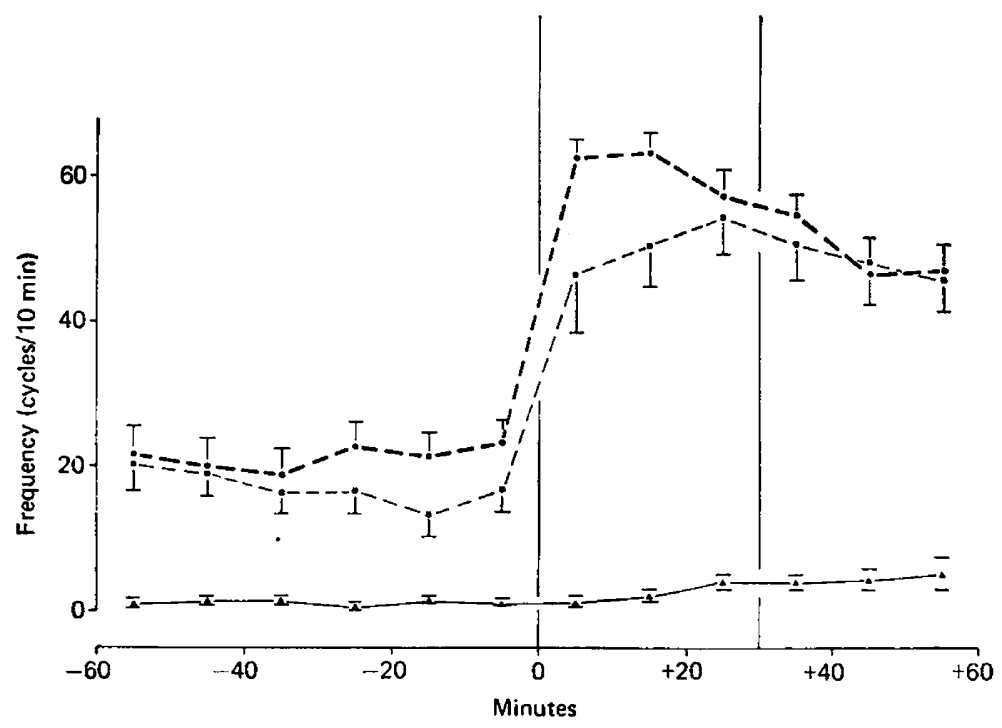

Text-fig. 4. Graph showing changes in frequency ( \pm s.e.m.) of intrauterine pressure cycles in response to a 30-min infusion (vertical lines) of PGF-2 $\alpha(10 \mu \mathrm{g} / \mathrm{min})$ performed during the Control (๑), Treatment $(\Delta)$ and Recovery $(\square)$ periods for 8 experiments with 4 ewes.

Oxytocin test. Oxytocin injected intravenously elicited a marked stimulation of the frequency of pressure cycles (Text-fig. 1). Immediately after injection frequency rose to 48 cycles $/ 10 \mathrm{~min}(P<0.05)$. Active pressure actually declined immediately following oxytocin treatment, but this was attributable to a marked elevation of the resting pressure (Text-fig. 2). The resting pressure gradually returned to normal and at the same time the amplitude of active intrauterine pressure increased to pretreatment levels. Total uterine activity was elevated above normal for about $50 \mathrm{~min}$.

$P G F-2 \alpha$ infusion. Intrauterine infusion of PGF- $2 \alpha$ elicited a significant increase in the frequency of pressure cycles to 63 cycles/10 min (Text-fig. 4). Resting pressure was only slightly elevated (Textfig. 3) and infusion of vehicle alone had no effect. Downloaded from Bioscientifica.com at 04/26/2023 10:00:11AM 


\section{Treatment period}

Spontaneous activity. During progesterone treatment spontaneous intrauterine pressure cycles declined steadily in both frequency and amplitude. The inhibition was maximal at $72 \mathrm{~h}$ after the first progesterone injection (Table 1) and maximum amplitude had fallen to less than $10 \mathrm{mmHg}$. Both of these values are significant at the $0.1 \%$ level, and the uterus was therefore rendered virtually inactive by the progesterone treatment.

Oxytocin test. There was almost no response to oxytocin in any of the ewes on Day 6, i.e. $72 \mathrm{~h}$ after the first progesterone injection (Text-figs 1 and 2 ).

$P G F-2 \alpha$ infusion. The pressure response to PGF-2 $\alpha$ was virtually absent in ewes in which spontaneous myometrial activity had been suppressed by progesterone (Text-figs 3 and 4). There was a slight increase in resting pressure (about $4 \mathrm{mmHg}$ ) but no significant increase in frequency of pressure cycles.

Table 1. Mean \pm s.e.m. frequency $($ cycles/h) of intrauterine pressure cycles on each of the 12 days of the 13-day treatment regimens for 4 ewes

\begin{tabular}{|c|c|c|c|c|c|c|c|c|c|c|c|c|}
\hline Day & 1 & 2 & 3 & $4^{*}$ & $5^{*}$ & $6^{*}$ & 7 & 8 & 9 & 10 & 11 & 12 \\
\hline Frequency & $\begin{array}{r}126.4 \\
\pm 20.1\end{array}$ & $\begin{array}{r}119.3 \\
+19.6\end{array}$ & $\begin{array}{r}104.6 \\
\pm 12.2\end{array}$ & $\begin{array}{r}96.5 \\
\pm 14.1\end{array}$ & $\begin{array}{r}55.5 \\
\pm 7.1\end{array}$ & $\begin{array}{r}17.8 \\
\pm 3.2\end{array}$ & $\begin{array}{r}7 \cdot 2 \\
\pm 3.2\end{array}$ & $\begin{array}{r}38.3 \\
\pm 7.4\end{array}$ & $\begin{array}{r}35.7 \\
\pm 7.1\end{array}$ & $\begin{array}{r}59.6 \\
\pm 9.7\end{array}$ & $\begin{array}{r}64.1 \\
\pm 12.1\end{array}$ & $\begin{array}{r}77.5 \\
+13.8\end{array}$ \\
\hline
\end{tabular}

* A s.c. injection of $50 \mathrm{mg}$ progesterone was given on these days.

\section{Recovery period}

Spontaneous activity. After the period when myometrial activity was maximally inhibited, there was a steady increase in frequency and amplitude of pressure cycles until, at approximately the 6th day after the last progesterone injection, the ewes exhibited levels of uterine activity comparable to about $75 \%$ of those of the Control period.

Oxytocin test and PGF-2 $\alpha$ infusions. Oxytocin injection (Text-fig. 1) and intrauterine PGF-2 $\alpha$ infusion (Text-figs 3 and 4 ) elicited responses similar to those obtained during the Control period.

\section{Progesterone levels}

Two of the 24 plasma samples yielded what appear to be extraordinarily high levels of progesterone $(27.2$ and $12.4 \mathrm{ng} / \mathrm{ml})$, especially since they were taken during Control (pretreatment) periods. Accordingly, these, and their associated results from Day $6(2.10$ and $1.60 \mathrm{ng} / \mathrm{ml})$ and Day $13(0.48$ and $0.42 \mathrm{ng} / \mathrm{ml}$ ) have been disregarded although these were comparable with the other sets. The remaining six groups of progesterone measurements are shown in Table 2.

\section{Latency period, rate of rise of pressure, and recovery}

The injection of $100 \mathrm{mg}$ progesterone was followed in all 4 ewes by a steady decline in the amplitude and frequency of contractions until minimal levels ( 1.6 cycles $/ 10 \mathrm{~min}$ and $14 \mathrm{mmHg}$ respectively) were reached at $48 \mathrm{~h}$ and maintained for at least $36 \mathrm{~h}$. Recordings at $8,12,20,24,34$ and $42 \mathrm{~h}$ after injection all showed activity greater than at $48 \mathrm{~h}$. Thus, in the ewe there is a latency of $48 \mathrm{~h}$ between

Table 2. Plasma progesterone levels $(\mathrm{ng} / \mathrm{ml})$ in ewes during 6 experimental periods

\begin{tabular}{cccc}
\hline Ewe & $\begin{array}{c}\text { Day 3 } \\
\text { (Control) }\end{array}$ & $\begin{array}{c}\text { Day 6 } \\
\text { (Treatment) }\end{array}$ & $\begin{array}{c}\text { Days 11-13 } \\
\text { (Recovery) }\end{array}$ \\
\hline $4(1)$ & 0.26 & 2.24 & 0.32 \\
$5(1)$ & 0.16 & 1.54 & 0.88 \\
$5(2)$ & 0.16 & 1.86 & 0.72 \\
$6(1)$ & 0.22 & 4.58 & 0.02 \\
$7(1)$ & 0.12 & 2.24 & 0.38 \\
$7(2)$ & 0.40 & 2.36 & 0.48 \\
Mean \pm s.e.m. & $0.22 \pm 0.04$ & $2.47 \pm 0.44$ & $0.47 \pm 0.12$ \\
\hline
\end{tabular}


injection of progesterone and its maximum effect on the myometrium. Recovery was apparent by $115 \mathrm{~h}$ when frequency had increased to about 10 cycles/10 min and amplitude to $18 \mathrm{mmHg}$. Full recovery to pretreatment levels was achieved on average by $200 \mathrm{~h}$ in both frequency and amplitude.

The rate of rise of the intrauterine pressure cycles before treatment was $5.07 \pm 0.88$ (s.e.m.) $\mathrm{mmHg} / \mathrm{sec}$. After progesterone injection the rate of rise declined and at the peak effect of the hormone at $48 \mathrm{~h}$ was $0.92 \pm 0.11 \mathrm{mmHg} / \mathrm{sec}$. As frequency and amplitude increased during recovery, so did the rate of rise of pressure and by $280 \mathrm{~h}$ it was $5.97 \pm 1.62 \mathrm{mmHg} / \mathrm{sec}$.

\section{Discussion}

These results indicate that progesterone has a marked, reversible, inhibitory action upon myometrial activity in the oestrogen-treated, ovariectomized ewe and are consistent, therefore, with the earlier reports that progesterone reduces myometrial activity. The present study has revealed that the nature of the inhibition is very similar to that observed in the progesterone-treated rabbit, i.e. it is a 'classic' progesterone 'block' as first described by Csapo (1956). During the onset of the progesterone 'block' in the ewe, the amplitude, and the rate of rise, of intrauterine pressure cycles declined steadily so that at the peak effect amplitude was often below the $10 \mathrm{mmHg}$ minimum adopted as a criterion for a 'pressure cycle', and 'activity' consisted of a continuous series of very small subliminal $(<10 \mathrm{mmHg})$ pressure cycles. In these respects the behaviour again closely resembles that of the progesterone'blocked' rabbit uterus (Csapo \& Takeda, 1965). Although we did not measure myometrial progesterone levels, this response to progesterone in the ewe may be assumed to be physiological for the following reasons: (1) the levels of progesterone produced in the blood by the $3 \mathrm{rd}$ day of the treatment $(2.47 \mathrm{ng} / \mathrm{ml})$ are comparable to those reported at the peak of the luteal phase in intact ewes (Stabenfeldt, Holt \& Ewing, 1969); (ii) the degree of inhibition of uterine activity is comparable to that observed during the luteal phase (Naaktgeboren et al., 1973; Lehrer \& Schindler, 1974; S. J. Lye \& D. G. Porter, unpublished data).

The comparison with the rabbit may be extended further because the progesterone-dominated ovine uterus is refractory to oxytocic agents. For example, $500 \mathrm{mu}$ oxytocin, which normally evoked at least a doubling of the frequency of pressure cycles, elicited no response at all in the progesterone'blocked' uterus. Even more striking was the total absence in the progesterone-treated ewe of a response to the intrauterine infusion of PGF-2 $\alpha$ at a rate of $10 \mu \mathrm{g} / \mathrm{min}$, which produced a 3-fold increase of frequency in the same animal before treatment.

It has been suggested (Liggins et al., 1977) that the activity of the ovine myometrium might simply reflect the prostaglandin secretory behaviour of the endometrium. Thus, if the supply of prostaglandins from the endometrium to the myometrium was reduced, for example by the action of progesterone, then myometrial activity would decline, whereas enhanced prostaglandin production by the endometrium would result in increased contractile activity of the myometrium. The present study provides no support for this hypothesis, because if progesterone acted on the endometrium alone, then intrauterine infusion of PGF- $2 \alpha$ should elicit a response in the myometrium of the progesteronetreated ewe similar to that observed in the untreated animal. The fact that the response is blocked argues for a direct action of progesterone on the myometrium, although this might not be so if transfer of PGs from the lumen to the myometrium was impaired by progesterone. This possibility would seem remote because synthesis of PGs by the endometrium is enhanced by progesterone (Louis, Parry, Robinson, Thorburn \& Challis, 1977) and Harrison, Heap \& Poyser (1976) have shown that both uterine fluid and uterine vein blood contain substantial amounts of PGs (i.e. synthesis and release are unimpaired) in ewes with high plasma progesterone levels. Furthermore, Roberts \& McCracken (1976) reported greatly attenuated uterine responses to PGF- $2 \alpha(15 \mu \mathrm{g} / \mathrm{h})$ infused into the uterine artery during the luteal phase, and we (S. J. Lye \& D. G. Porter, unpublished data) were unable to elicit a mechanical response in a progesterone-treated ovariectomized ewe with much larger doses of PGF- $2 \alpha$ given via either the uterine $(200 \mu \mathrm{g} / \mathrm{min})$ or the carotid (100 $\mu \mathrm{g}$, single injection), arteries. The lack of response to oxytocin also suggests that progesterone acts directly on uterine muscle. Uterine smooth muscle possesses specific oxytocin receptors (Soloff, Swartz, Morrison \&:11AM 
Saffran, 1973) and recent evidence suggests that the pathway by which the muscle is stimulated by oxytocin does not involve PGs (Roberts \& McCracken, 1976). It is difficult, therefore, to believe that the action of oxytocin on the sheep uterus could be abolished by an inhibitory action of progesterone on PG production by the endometrium.

The latency between injection and peak effect is much longer in the ewe ( $48 \mathrm{~h})$ than in the rabbit $(8-12 \mathrm{~h})$, as is the recovery period from peak effect $(120 \mathrm{~h}$ in the ewe, $48 \mathrm{~h}$ in rabbit). The explanations for these long latencies are not known. It is unlikely that recovery was delayed by sustained plasma progesterone levels since 6 additional plasma samples taken from ewes on Days 8 or 9 of the experimental regimens revealed that the levels had already fallen to less than $20 \%$ of the Day 6 value.

In the rabbit, progesterone impairs propagation of action potentials through the myometrium (Csapo \& Takeda, 1965) so that coordination of contractile activity is impaired, resulting in a reduction in both the amplitude of contraction and the rate of rise of muscle tension (i.e. intrauterine pressure). Both of these changes were noted in the present study. A further effect observed in the rabbit, an increase in frequency of contraction, attributed to the dissociation of the pacemaker units of the myometrium, was not observed but this may have been masked by our criteria for a contraction. Thus, when the progesterone 'block' was established, the uterus exhibited a high frequency of 'subliminal' pressure cycles. These findings, together with those of Naaktyihoren et al. (1973), support the view that progesterone impairs conductivity in the ovine myometrium.

It is possible that the gravid uterus might respond to progesterone quite differently from the nongravid uterus, but there is no evidence for this in other species. If parallels can be drawn between the ewe and the rabbit then the removal of the influence of progesterone on the uterine muscle must be a prerequisite for parturition. The fall in plasma progesterone levels which occurs before birth suggests that a removal of progesterone influence normally occurs, but there are data which raise doubts about the extent of this 'withdrawal'. First, the decline in plasma progesterone is more abrupt in the ewe than in the rabbit (compare data from Bassett et al., 1969, for the ewe, with those of Challis, Davies \& Ryan, 1973, for the rabbit) and, in view of the time required for recovery in the present experiments, may not be rapid enough to permit significant uterine activity and pharmacological reactivity to evolve. Also, the almost total absence of myometrial activity which persists until within $12 \mathrm{~h}$ of birth (Hindson, Schofield \& Turner, 1968; Rawlings \& Ward, 1976; unpublished data) suggests that either the progesterone 'block' is removed immediately before parturition, or that another myometrial inhibitor prevents the evolution of uterine activity during the withdrawal of the progesterone 'block', as has been shown in the rabbit (Porter, 1974). In the rabbit plasma levels of progesterone have to be very low to permit uterine activity to develop (Challis, Porter \& Ryan, 1974).

It is difficult to reconcile these conclusions with the work of Rawlings \& Ward (1976), who found that although myometrial progesterone levels were lower than at Day 130 of pregnancy they did not decline significantly during the 8 days preceding birth, and with the report of Liggins et al. (1972) that parturition proceeded in ewes with high myometrial titres of progesterone. However, the present experiments suggest that these conflicting findings must be reconciled, and if neither is wrong it is possible that a mechanism operates in the ewe which reverses the progesterone 'block' in the presence of the hormone.

We are grateful to Mrs Mary Stanley for her expert care of the experimental animals and technical assistance, and to Dr M. Dukes, I.C.I. Laboratories, Alderley Park, Cheshire, for generously providing the prostaglandin. The work was made possible by a grant from the Agricultural Research Council, AG7/63.

\section{References}

ARmitage, P. (1971) Statistical Methods in Medical Research. Blackwell, Oxford.

Bassetr, J.M., Oxborrow, T.J., Smith, I.D. \& ThORBuRN, G.D. (1969) The concentration of progesterone in the peripheral plasma of the pregnant ewe. J. Endocr. 45, 449-557.
Bengtsson, L.Ph. \& Schofield, B.M. (1963) Progesterone and the accomplishment of parturition in the sheep. J. Reprod. Fert. 5, 423-431.

CARrick, M.J. \& CupPS, P.T. (1976) Interactions between steroids and spasmogens on the myometrium Dof the ewe. $\boldsymbol{J}$. Reprod. Fert. 46, 512, Abstr. $26 / 2023$ 10: $00: 11 \mathrm{AM}$ 
Challis, J.R.G., Davis, I.J. \& Ryan, K.J. (1973) The concentrations of progesterone, estrone and estradiol$17 \beta$ in the plasma of pregnant rabbits. Endocrinology 93, 971-976.

Challis, J.R.G., Porter, D.G. \& Ryan, K.J. (1974) The effects of prostaglandin $F_{2 \alpha}$ and ovariectomy on the peripheral plasma steroid concentrations and the evolution of myometrial activity in the pregnant rabbit. Endocrinology 95, 783-792.

Croker, K.P. \& Shelton, J.N. (1973) Influence of stage of cycle, progestagen treatment and doses of oestrogen on uterine motility in the ewe. J. Reprod. Fert. 32, 521-524.

Csapo, A.L. (1956) Progesterone block. Am. J. Anat. 98, 273-291.

CSAPO, A.I. \& TAKEDA, H. (1965) Effect of progesterone on the electric activity and intra-uterine pressure of pregnant and parturient rabbits. Am. J. Obstet. Gynec. 91, 221-231.

FylLiNG, P. (1969) The effect of pregnancy, ovariectomy and parturition on plasma progesterone level in sheep. Acta endocr., Copenh. 65, 273-283.

Harrison, F.A., Heap, R.B. \& Poyser, N.L. (1976) Production, chemical composition and prostaglandin $\mathrm{F}-2 \alpha$ content of uterine fluid in pregnant sheep. $J$. Reprod. Fert. 48, 61-67.

Heap, R.B., Gwyn, M., Laing, J.A. \& Walters, D.E. (1973) Pregnancy diagnosis in cows; changes in milk progesterone concentration during the oestrous cycle and pregnancy measured by a rapid radioimmunoassay. J. agric. Sci., Camb. 81, 151-157.

Hindson, J.C., Schofield, B.M., Turner, C.B. \& WolfF, H.S. (1965) Parturition in the sheep. $J$. Physiol., Lond. 181, 560-567.

Hindson, J.C., Schofield, B.M. \& Turner, C.B. (1968) Parturient pressures in the ovine uterus. $J$. Physiol., Lond. 195, 19-28.

LeHRER, A.R. \& SCHINDleR, H. (1974) Uterine motility of the ewe during the estrous cycle. J. Anim. Sci. 38, 86-88.

Liggins, G.C. (1973) Hormonal interactions in the mechanism of parturition. Mem. Soc. Endocr. 30, $119-139$.

Liggins, G.C., Grieves, S.A., Kendall, J.Z. \& Knox, B.S. (1972) The physiological roles of progesterone, oestradiol-17 $\beta$ and prostaglandin $F_{2 \alpha}$ in the control of ovine parturition. J. Reprod. Fert., Suppl. 16, 85103.

Liggins, G.C., Fairclough, R.J., Grieves, S.A., Forster, G.S. \& KNox, B.S. (1977) Parturition in Sheep. In The Fetus and Birth (Ciba Foundn Symp. No. 47), pp. 5-25. Eds J. Knight \& M. O'Connor. Elsevier, Amsterdam.

Louis, T.M., PARRY, D.M., Robinson, J.S., ThORBURN,
G.D. \& Challis, J.R.G. (1977) Effects of exogenous progesterone and oestradiol on prostaglandin $F$ and 13,14-dihydro-15-oxo prostaglandin $F_{22}$ concentrations in uteri and plasma of ovariectomized ewes. J. Endocr. 73, 427-439.

NaAktgeboren, C., Van der Weyden, G.C., Klopper, P.J., Kroon, C.H., Schoof, A.G. \& Taverne, M.A.M. (1973) Electrophysiological observations of uterine motility during the oestrous cycle in sheep. J. Reprod. Fert. 35, 511-518.

PORTER, D.G. (1974) Myometrial regulation in the pregnant rabbit: evidence for a "new" hormone. Biol. Reprod. 10, 54-61.

PORTER, D.G. (1977) Contribution to discussion. In The Fetus and Birth (Ciba Foundn Symp. No. 47), p. 28. Eds J. Knight \& M. O'Connor. Elsevier, Amsterdam.

Rawlings, N.C. \& WARD, W.R. (1976) Changes in steroid hormone in plasma and myometrium and uterine activity in ewes during late pregnancy and parturition. J. Reprod. Fert. 48, 355-360.

Roberts, J.S. \& MCCRACKen, J.A. (1976) Does prostaglandin $F_{2 x}$ released from the uterus by oxytocin mediate the oxytocic action of oxytocin? Biol. Reprod. 15, 457-463.

Rousseau, J.P. \& Prud'Homme, M.T. (1974) Etude electromyographique de la motricité de l'utérus chez la brebis. Action des hormones. Annls Biol. anim. Biochim. Biophys, 14, 67-85.

RUCKeBUSCH, Y. \& BUENo, L. (1976) An electromyographic study of uterotubal activity in the ewe. $J$. Reprod. Fert. 47, 221-227.

SCHOFIELD, B.M. (1957) The hormonal control of myometrial function during pregnancy. J. Physiol., Lond. 138, $1-10$.

Soloff, M., Swartz, T., Morrison, M. \& Saffran, M. (1973) Oxytocin receptors: oxytocin analogues but not prostaglandins compete with $3 \mathbf{H}$ oxytocin for uptake by rat uterus. Endocrinology 92, 104-107.

Stabenfeldt, G.H., Holt, J.A. \& Ewing, L.L. (1969) Peripheral plasma progesterone levels during the ovine estrous cycle. Endocrinology 85, 11-15.

Stabenfeldt, G.H., Drost, M. \& Franti, C.E. (1972) Peripheral plasma progesterone levels in the ewe during pregnancy and parturition. Endocrinology 90, 144-150.

ThOMPSON, F.N. \& WAGNER, W.C. (1974) Fetal-maternal corticosteroid relationships in sheep during late pregnancy. J. Reprod. Fert. 41, 49-56.

Thorburn, G.D., Nicol, D.H., Bassett, J.M., Shutt, D.A. \& Cox, R.I. (1972) Parturition in the goat and sheep: changes in corticosteroids, progesterone, oestrogens and prostaglandin $\mathrm{F}_{2 x} . J$. Reprod. Fert., Suppl. 16, 61-84. 